\title{
THE REUSE OF HOUSING BUILDINGS IN BARCELONA THE VERSATILITY OF OLD CONSTRUCTIVE STRUCTURES
}

\author{
MAGDA MÀRIA ${ }^{1 *}$, XAVIER MONTEYS ${ }^{2}$ \\ ${ }^{1}$ Departament de Projectes Arquitectònics (DPA) \\ Universitat Politécnica de Catalunya (UPC-BarcelonaTech) \\ Campus Sud UPC \\ Av. Diagonal, 649. $5^{\text {a }}$. pl. 08028 Barcelona, Spain \\ e-mail:magda.maria@upc.edu,web page: https://habitar.upc.edu \\ (*corresponding author) \\ ${ }^{2}$ Departament de Projectes Arquitectònics \\ Universitat Politècnica de Catalunya \\ Campus Sud UPC \\ Av. Diagonal, 649. $5^{\text {a }}$. pl. 08028 Barcelona, Spain \\ e-mail: xavier.monteys@upc.edu,web page: https://habitar.upc.edu
}

Keywords: reused housing buildings, Barcelona, bearing walls, buildings transformed into housing, adaptive reuse

\begin{abstract}
.
There are 1,463 buildings in Barcelona, from different times from the first century to the present day, that have changed their functions once or more times throughout their life. This paper analyses those cases in which changes in use relate to housing and it does it in two opposite ways: In one way, examining houses -mostly with building structures of bearing walls - that have endured functional modifications without losing its main attributes. In the opposite way around, studying buildings with other uses than housing many of them built with isotropic structures or large structural spans- that have been converted into dwellings. On the other hand, and in both cases, the analysis addresses how the urban situation of the building conditions the use to which it will tend to be transformed.
\end{abstract}




\section{INTRODUCTION}

In a recent study, made by our research group on the reuse of buildings in Barcelona, we have identified 1,463 cases of buildings that, from the 1 st century to the present [1], have changed their use once or more times. Of all the existing uses - housing, residential, commercial, offices, industrial, sanitary, religious, cultural, recreational, educational, sports and institutional - housing has contributed the most to accommodate new uses: A $55.52 \%$, of the reused buildings in Barcelona were originally homes. It is a high figure compared to a 5.89\% of other buildings that, having other original functions, have been converted into housing.

Quantitatively this data has its logic since housing makes up much of the urban fabric of a city; in fact, in Barcelona it entails a $98 \%$ of it. However, it is a paradox that structures that respond to domestic requirements have had the capacity to host uses and programs that intrinsically seem to require very different conditions.

Much of the houses in Barcelona are built with wearing walls. Their structural spans delimit stairs, patios and rooms of small or large size, that fit into this structural system. They have constructive and spatial qualities that differ markedly from, for example, those of industrial buildings, composed of large naves and open structures that seem more in line with versatility and, therefore, to house a wide range of functions.

This leads us to believe that the apparent rigidity of the structural system of Barcelona's dwellings does not impede their predisposition to changing use. Furthermore, it induces us to analyze how houses, with their various typologies, have endured functional alterations without

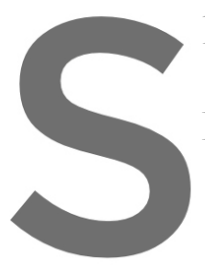
losing their main consitr
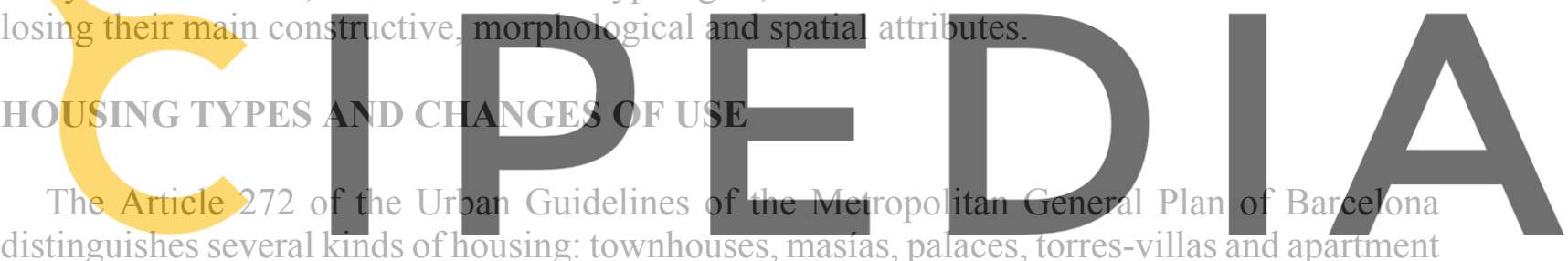

distinguishes several kinds of housing: townhouses, masias, palaces, torres-villas and apartment

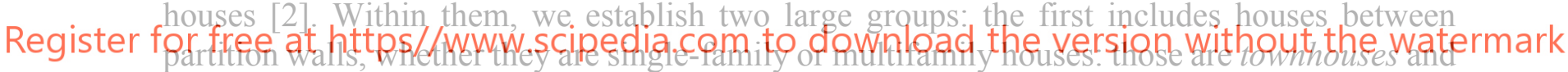
apartment buildings; the second, includes freestanding houses: masias, palaces and torrevillas.

The townhouses are built between partition walls ranging from modest constructions in municipalities added to Barcelona, such as Sant Andreu, Sarrià-Sant Gervasi or Sants, to unique houses in the Eixample or Ciutat Vella. They usually have a back yard and they generally belonged to one family that occupied the entire property. They constitute a $31.1 \%$ of the houses that have changed their use and, in their transformation, some of the most outstanding ones have hosted cultural functions, as in the case of the Elizalde house, or the Ametller house; while commercial programs have colonized many others.

The apartment buildings are composed of several units, initially for renting and usually with two apartments per floor that occupy the entire depth of the plot. They are mostly built with brick-bearing walls that also support the interior courtyards and stairwells. The rooms are usually very regular, especially in the buildings of the Eixample layout by Cerda. They make up to a $34.0 \%$ of the homes that have changed their use and their foreseeable transformation has led them to become residential buildings such as hotels, residences, youth hostels or tourist apartments. An example of this would be the Fuster House, converted into Hotel Casa Fuster. 
The masias are freestanding constructions, with a three naves structure, that consist of ground floor, main floor and garret. Some have large side galleries added. They were originally destined for housing and, together with the surrounding land, formed productive units linked to agriculture and livestock. Due to the expansion of the city, smaller plots than the original ones currently surround them. They are scattered in the urban fabric, mostly in the strip parallel to the Sierra de Collserola. They make up to the $5.7 \%$ of homes that have changed their use, covering very diverse functions: cultural, educational or commercial. An example is Can Cortada, a farmhouse converted into a restaurant.

The palaces are buildings intended for housing, built both between partition walls and freestanding. One of their distinctive features is the presence of a central courtyard with a noble staircase of access to the first floor, visually linked to the entrance. They constitute a $6 \%$ of the homes that have changed their use, and many of them are concentrated in Ciutat Vella, as the Palacio de la Virreina, converted into a cultural center.

The torre-villas are houses built exclusively as freestanding constructions, usually surrounded by a garden. They represent a similar case to that of the palace, but with a more clearly domestic program. They make up to a $23.2 \%$ of the houses that have changed their use and their construction is mainly concentrated in the district of Sarrià-Sant Gervasi, in the upper part of Gracia or in Horta-Guinardó. As in the case of the masías, their new functions are very heterogeneous, but they gather similar uses in certain streets or sectors of a district, such as the educational use nearby the Paseo de Sant Gervasi or the Paseo Bonanova.
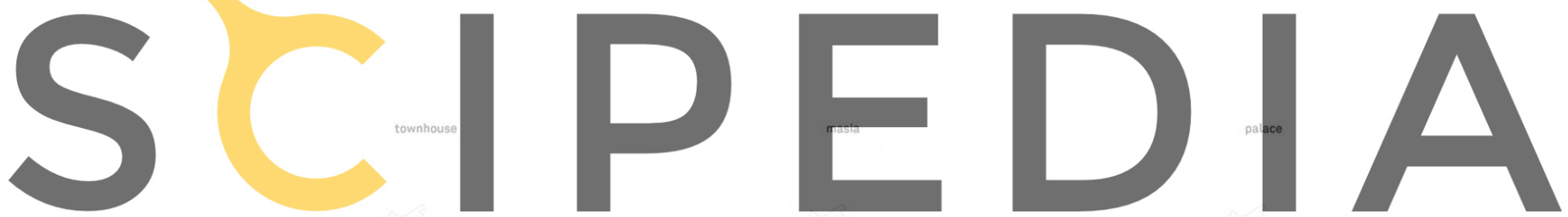

Register for free at https//www.scipedia.com to download the version without the watermark
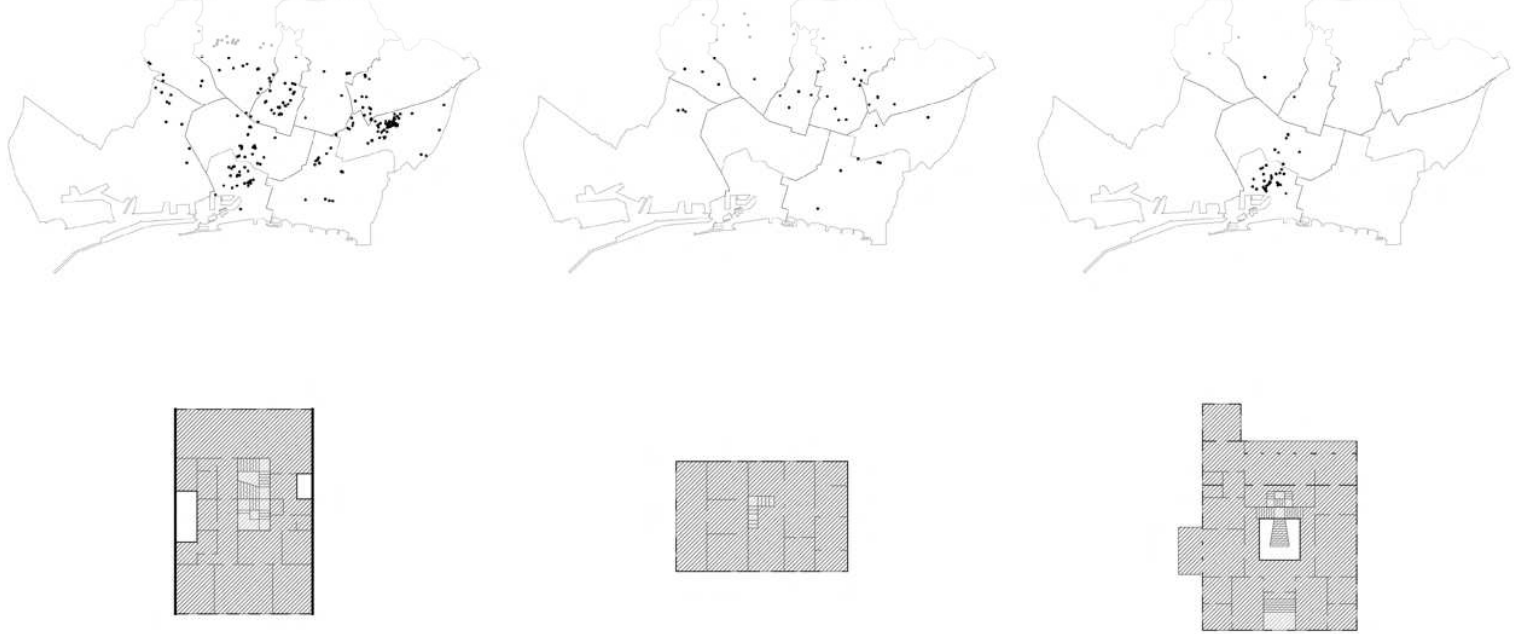

Figure 1a: Scheme of the different types of housing and its urban location 


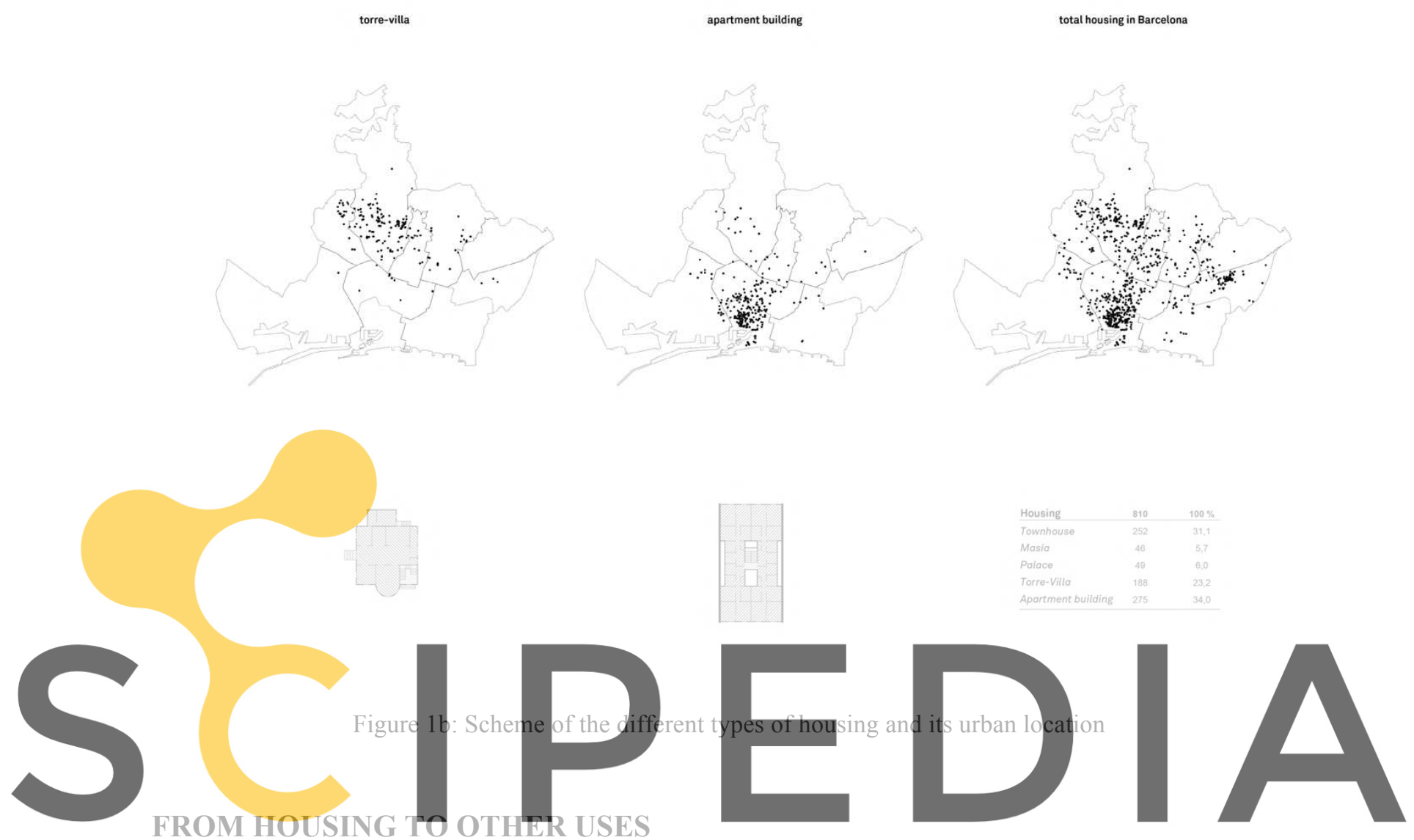

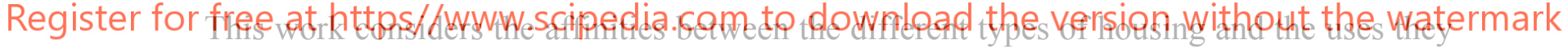

have embraced throughout their useful life. But also, comparatively, values buildings that, having other programs in their origin, have become homes. We call this the double way of housing use': from housing to other uses and from other uses to housing (Figure 2).

The first "one way of transformation" analyses the 810 dwellings that have changed use in Barcelona. As shown in Figure 3, they have been adapted to all the uses listed in the Metropolitan Master Plan Regulations. However, depending on the type of house/apartment, some final uses predominate over others. This gives us the opportunity to understand the logics that bring the original use to the current one, from the perspective of its typology, its structure and its location in the city.

One of the most frequent affinities between uses is the one between 'housing use' and 'residential use', thus: of the 331 buildings that have been turn into 'residential use', 270 were dwellings (an 81.8\%). On the other hand, if we consider that, of the 810 dwellings, 270 have changed its use into a residential one; we find that this is the prevailing program, with a $33.0 \%$, followed by the 'educational use' with a $19 \%$ and the 'commercial use' with a $14.3 \%$. 


$\begin{array}{rc}\text { housing } & 3,30= \\ \text { residential } & 33,30 \\ \text { commercial } & 14,30 \\ \text { offices } & 3,30 \\ \text { industrial } & 1,20= \\ \text { sanitary } & 3,80 \\ \text { religious } & 1,40= \\ \text { cultural } & \text { 7,70 } \\ \text { recreational } & 3,60= \\ \text { educational } & 19,00= \\ \text { sports } & 0,50, \\ \text { institutional } & 3,60=\end{array}$

from housing to other use

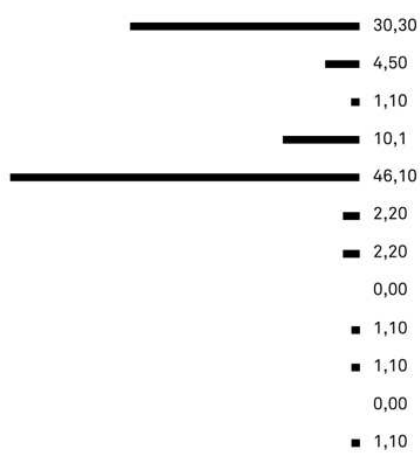

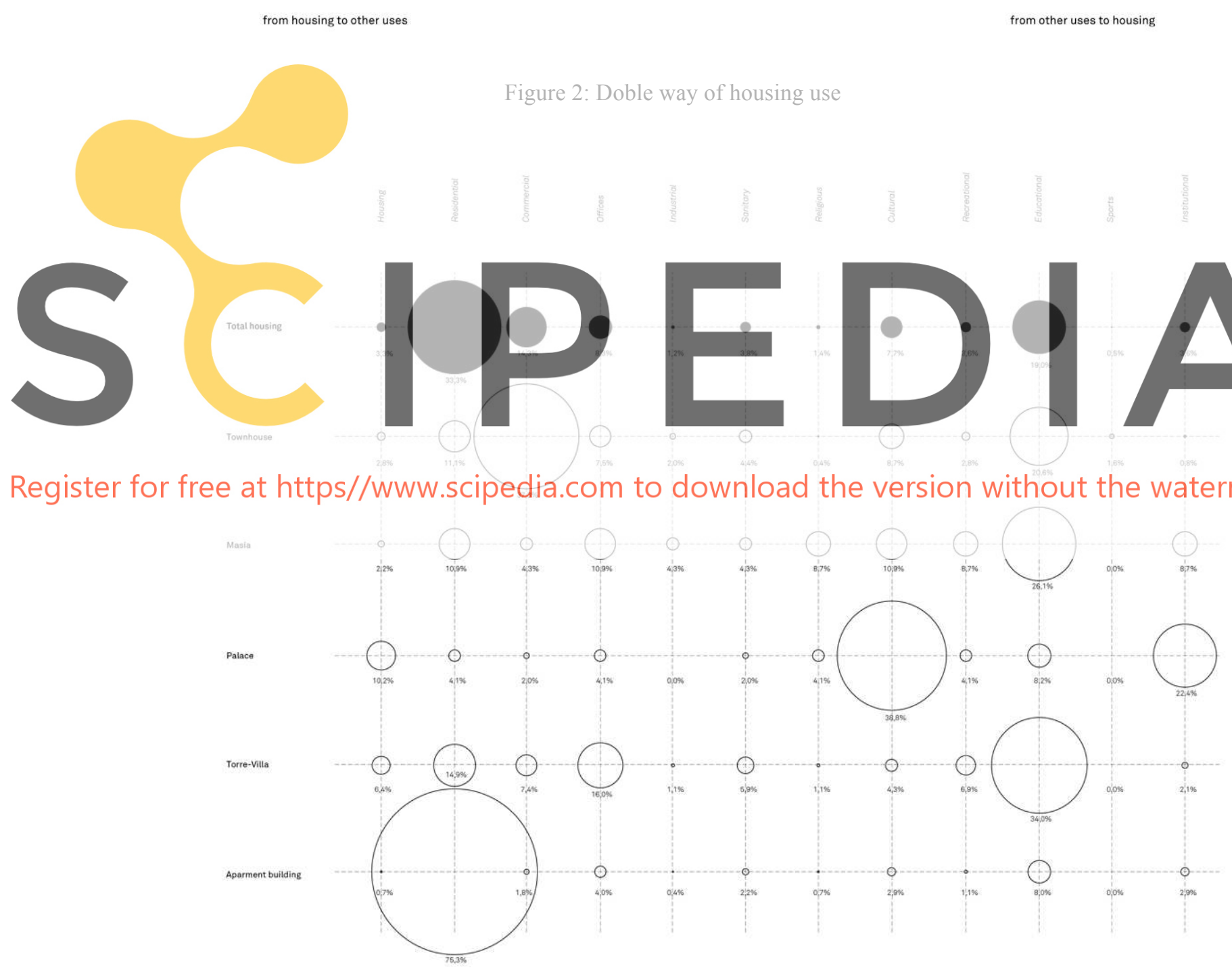

Figure 3: From housing to other uses 
We also observe that the apartment building typology would represent the greater typological correlation between the established five types of housing and the 'residential use'. A $75.3 \%$ of transformed apartment buildings have been converted into hotels, touristic apartments, youth hostels and, to a lesser extent, into geriatric or student residences. Concerning the location, a $44.8 \%$, that is, almost half of the buildings converted into 'residential use' are in Ciutat Vella and a quarter, a 25.6\%, are in the Eixample. Another alarming significant statistical figure is, due mostly to the boost of the hotel business in Barcelona, that an $88.3 \%$ of the buildings that have moved to 'residential use' - mainly hotels in Ciutat Vella, come from the 'housing use', and that explains the depopulation of the historic center of the city.

There are many examples of these transformations. Among them, we may highlight the Casa Joan Serra, located in Ciutat Vella, designed in 1867 by Francisco de Paula Villar and converted into the Hotel Montecarlo in 2000, after having been the headquarters of Las Noticias and El Correo Catalán newspapers. Another example is Casa Enric Batlló, located in the Eixample and designed in the late nineteenth century by Josep Vilaseca, with a new hotel use since the mid-1990s, according to Jordi Romeu's design project.

\section{Another significant concordance is that between 'housing use' and 'educational use'. Of the} 242 buildings currently hosting educational programs, including schools, academies and universities, 154 have been dwellings before: that is a $63.3 \%$. Among them, the types that have tended the most to adapt their spaces to schools have been the freestanding buildings, the

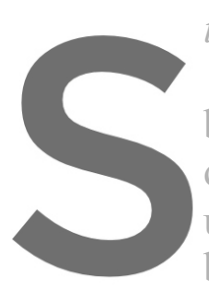
torre-villas being the

\section{Concerning their} buildings, 63 of them data with the maps of uses' that settle in existing between the interior oro


presence of a garden, with the spatial needs of a wide range of educational programs.

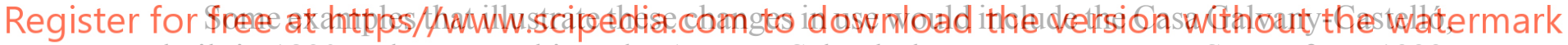
built in 1890 and converted into the Augusta School; the torre at Muntaner Street, from 1923, transformed into the Nausica School in 1969; or the masía can Fargas, originally from 1300, recently transformed into the Municipal School of Music.

Another remarkable case is that of the palaces. They have been destined firstly for 'cultural use', up to a $38.8 \%$, secondly for 'institutional use'. This may have an explanation in the role they play as part of the city memory, but it is also because of their spatial access features: with a direct link through a patio between the entrance and the noble first floor.

The other type of housing, the urban houses, has tended to transform into 'commercial use', specifically a $37.7 \%$ of them. This use includes small shops or restaurants that take advantage of the uniqueness of the property and, in some cases, of the backyard, to adapt its new functions properly.

A notable example of palace that has been turned into 'cultural use' could be the Palace of La Virreina, built on Las Ramblas in 1772, which has been hosting several museum programs since 1935 and that, currently, functions as an Art Center. The Palau Robert as well, built on Paseo de Gracia in 1898, became the Consejería de Cultura of the Generalitat in 1939, and it has ended up being a Cultural Center since 1997. 

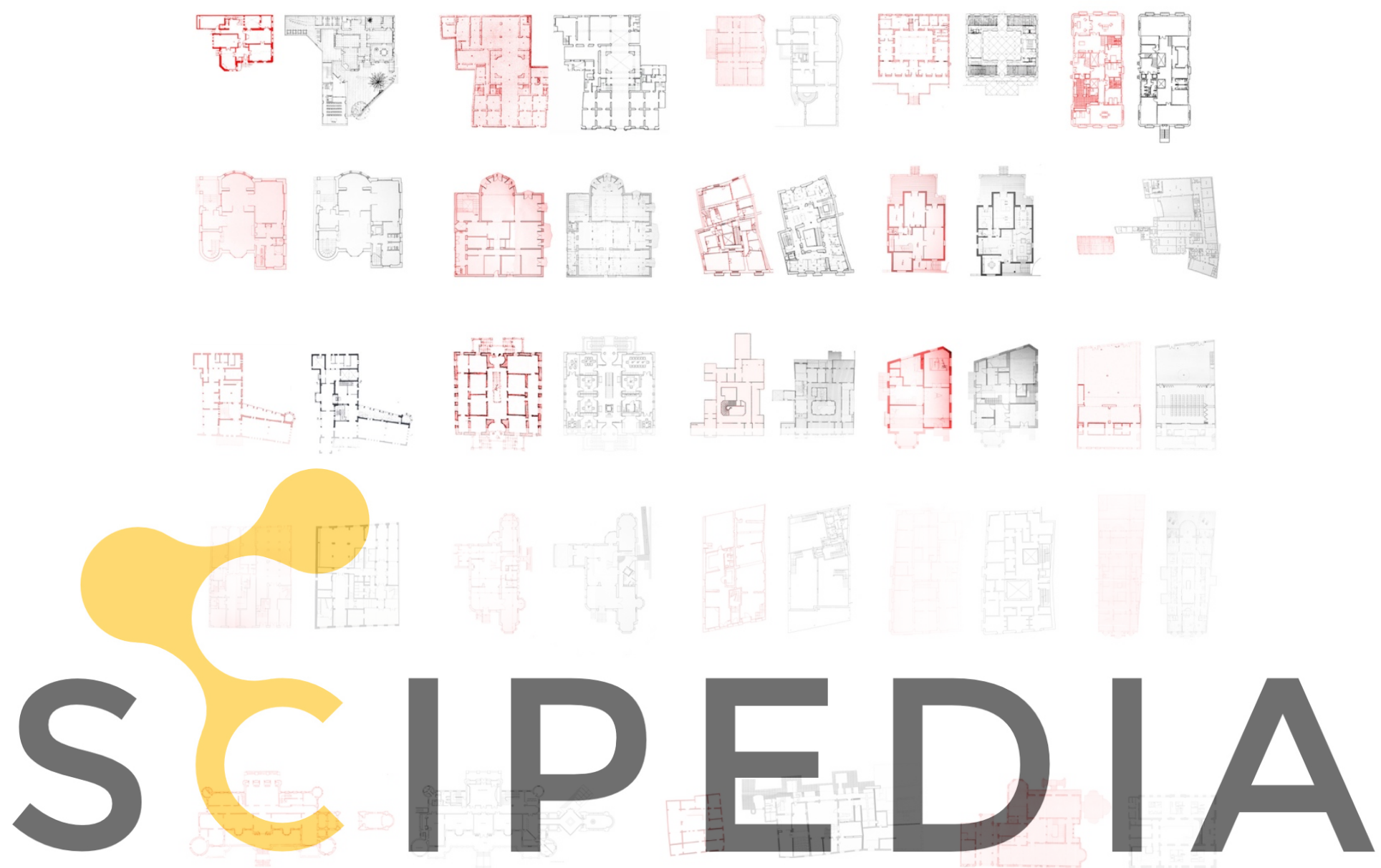

Register for free at https//www.scipedia.com to download the version without the watermark
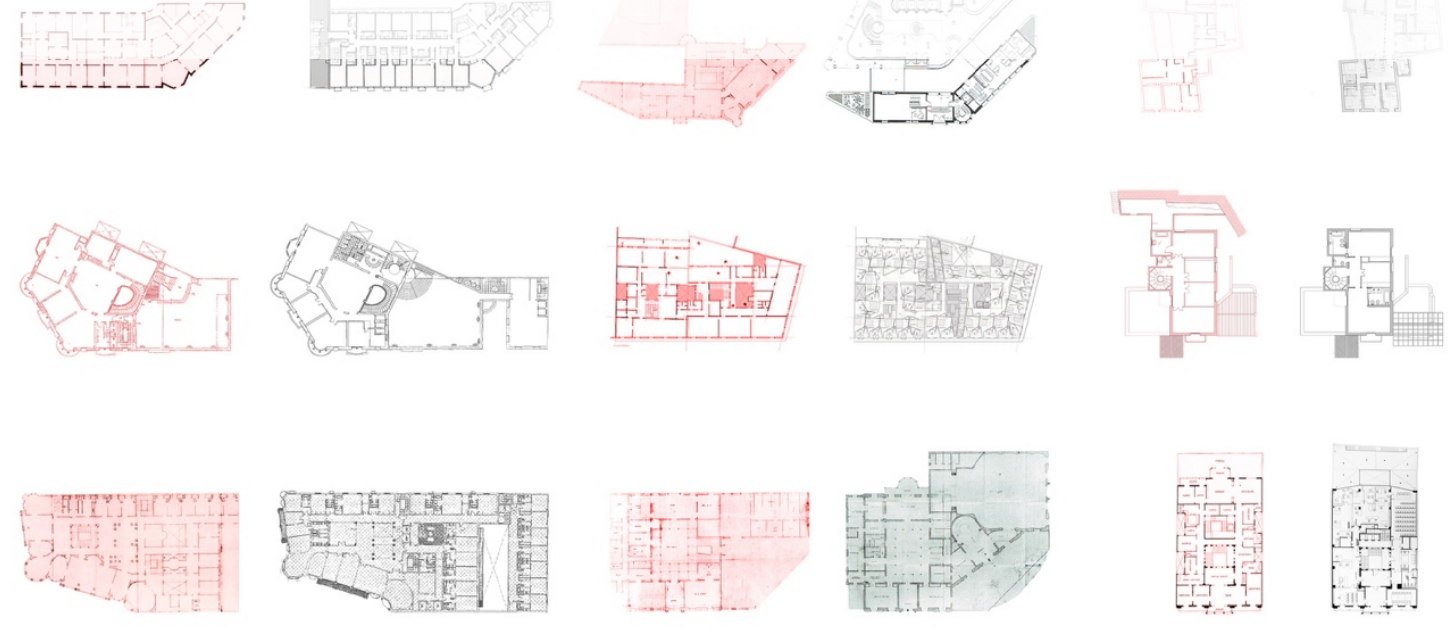

Figure 4: Housing types that have changed their use 


\section{FROM OTHER USES TO HOUSING}

The second way of the housing change of use, and in opposite direction, analyses those properties that, in origin, had other uses (either residential, commercial, offices, industrial, sanitary, religious, cultural, recreational, educational, sports or institutional) and that, over time, have become housing. The affinities found between the housing building and another functional programs implemented in them are very different from those found in the opposite direction of change of use, that is, the 89 buildings that had other uses and have change to a domestic new program.

In this case, the first thing that is seen is a change that has occurred in the dwelling culture over the last decades: the new ways of life and their link to the decrease in the average occupation of the houses have involved a reduction of the required domestic dimensions. Moreover, the popularization, since the 1990s, of the loft typology in Barcelona, has led to interior organizations in which different degrees of intimacy coexist in the same space.

These changes in dwelling culture have led to an easier adaptation of domestic functions to space structures that in the first place related very little to them, such as office buildings, warehouses, or industrial buildings. In fact, a $46 \%$ of the buildings that have switched into 'housing use' originally had an 'industrial use'. Most of this $46 \%$, up to a $92.6 \%$ of them have done so specifically into apartment buildings and the remaining $7.4 \%$, into urban houses.
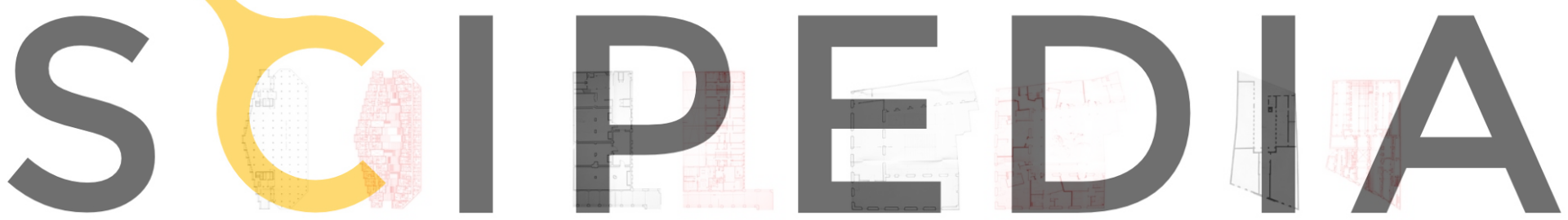

Register for free at https//www.scipedia.com to download the version without the watermark
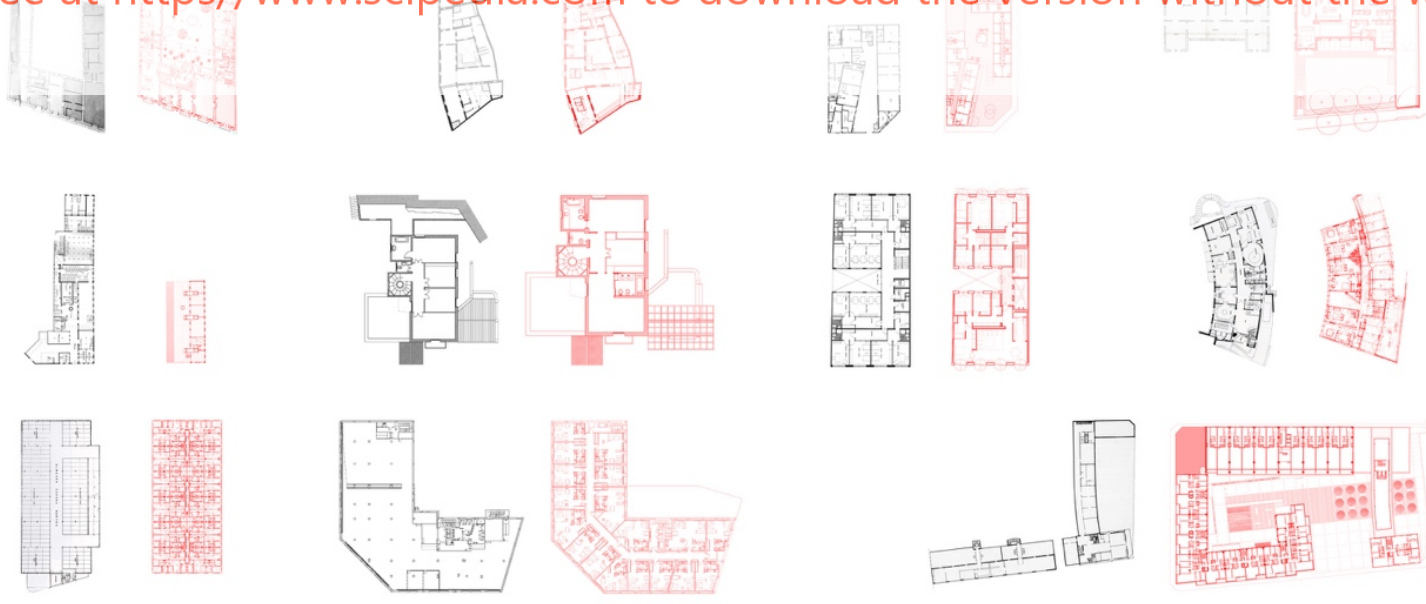

Figure 5: Other types that have become housing 
This typological correlation between industrial buildings and housing buildings is very common in the district of Sant Martí, mainly due to the conversion of many factories and warehouses into loft-type dwellings. An example of it would be the Industrias Agrícolas Company, a factory from 1911, converted into Passatge del Sucre lofts by Jordi Garcés in 2010. In addition, we also find other cases in districts such as Ciutat Vella or Gracia, where small industries or workshops have been transformed into domestic spaces.

\section{FIVE LESSONS ON THE “TWO WAYS" OF THE HOUSING USE}

The reprogramming potential of these architectures - many of them with equivalent rooms and bearing walls - to suit other functional programs is, at least, equivalent to the definition of 'flexibility' and therefore of 'freedom', as canonized by the Modern Movement. That is why we develop next an intentional analogy through Five Lessons on the "two ways", testing them in parallel with the well-known Le Corbusier's Five Points of a New Architecture' of [4].

The first lesson shows that, in the formal structure of housing, the regularity, repetition on series of some elements must be considered. As the main organizational and structural elements of buildings -such as courtyards or stairs- are crucial for a different use to be coupled in the least traumatic way; the regularity that concerns both the rooms or the parts, as well as the facade or roof elements, plays a decisive role in the preservation of its structural and constructive characteristics.

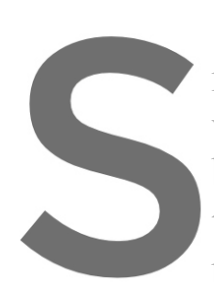

In most examples

rooms, have been crucia way with educational by equivalent rooms their various spaces program or the students
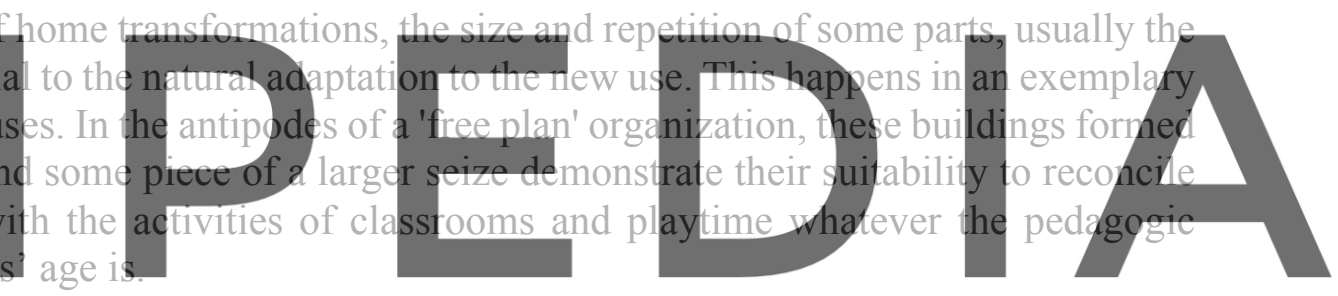

This also occurs in a similar way in office programs, whether from companies or official

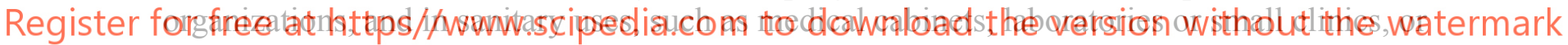
in commercials, such as retail sales or catering establishments. All these functions have been coupled to the structure of the house, arranging offices, doctor's cabinets, dining rooms, waiting rooms or meeting rooms inside existing bearing walls' structures.

Qualities as regularity, repetition or series concern not only to the pieces of the dwellings but also to other elements such as windows. In this sense, it is revealing that some of the buildings that have gone from ' offices use ' to ' housing use ' successfully, are built with bearing facades with windows, and not with curtain walls. The window, in these cases, becomes the module that is equivalent to a lounge and that can easily become a room.

The paradox is that, both the regular pieces built by bearing walls, as well as the bearing facades with windows, are the opposite of the diaphanous floors and curtain facades. The latter have an obvious relationship with two of the slogans coined by Le Corbusier in their 'Five points of a new architecture': the free plan and the free facade [4]. Qualities that, without discussion, have been considered for decades as key elements for the versatility of buildings and, obviously, guarantors of their flexibility.

However, the lounges and rooms of a house, prove that they can become classrooms of a school, dining rooms of a restaurant, showrooms of a museum, offices of a company or doctor 
offices. If they are not flexible according to the terminology of the modern movement, they are at least, ambiguous and therefore suitable for the requirements of a new use.

The second lesson leads us to recognize that the spatial organization of the house is presented as the most genuine pattern of architecture. We check how the house allows practically all uses, perhaps because we always carry its built-in scheme, especially in terms of the physical relationship with the built space.

In some functional programs, such as schools, this domestic organizational scheme is even beneficial. Pedagogical systems of active education, for example, aim to help children learn to reason for themselves about everyday events. At the same time, attention to their emotional needs requires that the areas where they carry out activities be like domestic ones. These requirements, in terms of space, fit perfectly into a house's functional program, and this explains why many schools have been installed in torres-villa or townhouses. In this sense, we could say that 'the house educates'. Likewise, these learning systems encourage contact with the outdoors and with nature, which also brings students health benefits. The garden of these urban houses thus becomes a very suitable and appreciated place.

In the third lesson we recognize that the torre-villas, houses and palaces have a special component, sometimes accentuated by their isolated status and because, in many cases, they have become part of the city's history. We can say that all of them are 'singular', and this quality has undoubtedly been one of the requirements for attracting new uses. In relation to this, we realize that the location and the conditions of the urban environment of these unique buildings determine the nature of the new uses to implement in them. The affinities that some functions have in relation to certain parts of the city denonstrates it: Sarrià-Sant Gervasi seems to have
specialized in reconverting torre-villas and houses into schools, and Ciutat Vella presents itself
as the district of choide to transform the palaces into cultural and institutional uses.
The fourth lesson tells us that the structural, morphological and spatial changes that, to a
greater or lesser extent, these houses undergo in their functional re-organization ane impottant factors to consider. In general, when reused, dwellings are stripped off the domestic life's most

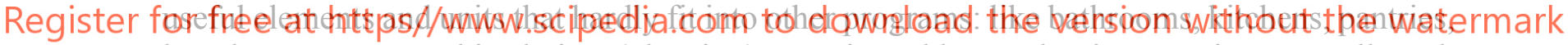
laundry rooms, etc. This obvious 'cleaning' operation adds up other interventions as well, such as the placement of facilities devices, lifts, or complementary volumes. In many cases, this has distorted the meaning of the original layout, disfiguring the domestic component and eliminating the decoration. However, on the other hand, we must recognize that, without these operations linked to the change of use, many of these buildings would have completely disappeared. In a sense they have not been 'museized', which would equal to 'freezing' their spaces, denying them the ability to remain in use. It would be fair to acknowledge that we can compare these changes to those undertaken by a new homeowner to fit their lifestyle.

Finally, the fifth lesson concerns the second way of 'housing use': The one in which buildings of different programs have become dwellings, and we observe in them, that serial regularity as in the rooms of a house - is also an important factor. Most strategies for re-use of factories, warehouses, offices, sports facilities or religious institutions are often based on the adaptation of living units - whether rooms, or apartments - to patterns of Repeat. These are often the result of the structural pattern, whether of bearing walls or pillars, of the host building. In addition, the rhythm in the arrangement of the windows in the facades of the host buildings facilitates the coupling of the housing program. 
The difference between office or industrial buildings with curtain wall, such as the SEAT car depot in The Plaza Cerda, and the buildings with windows, such as the Caja de Ahorros Provincial at 257 Rosselló Street, or the one at 245 Diputació street, is that in these last two the windows seem to digest better the change to housing. In these cases, the windows are synonymous with opening and their dimensions match those of the rooms, prefiguring the distribution in domestic-sized spaces.

\section{CONCLUSIONS}

By reviewing all the cases of the two ways of the 'housing use change' we find that not only the shape and building structure of the properties with various programs - that are transformed into houses - are flexible, but that also the houses themselves are of a great flexibility.

In the first way, it is the 'housing use' that, simply, allows the compartmentalized spaces to be over time other things and host other activities, after all, human. The 'housing use', with its formal patterns of entry, hierarchy of pieces but also the equivalence of rooms, with its activities differentiated by plants, with the central vocation of certain spaces, or with the unquestionable practical idea that they contain services, storage and grooming units predispose a functioning that invites reconciliation with many other uses.

We could say that the house 'educates use'. The house is, making an analogy like the clothes we wear: most of the day are the same, both for work and to carry out social or family activities. This is especially evident in the case of the torre-villas, much of them located in the districts of Sarrià-Sant Gervasi, in the upper part of Gracia or in Horta-Guinardó.

In the other way around, although the number of cases is much lower, it is again the 'housing use', especially considered from a contemporary perspective, which allows to be coupled to very heterogeneous spaces. Today, when profound changes are affecting the house - due to the current social structure, economy or lifestyles - the 'housing use' has been simplified and detached from several prejudices. Due to the reduction of dimensions and the tendency to informality, activities such as cooking, eating, working or even sleeping come together in the same space.

On the other hand, in Barcelona, the number of people living alone, as well as those who spend most of their time away from home, has increased. In addition, the city offers a series of services that directly affect the functions we associate with the house. All this makes it possible that, unlike a few decades ago, a series of spaces, that due to their environmental and structural conditions would not have offered the conditions of 'habitability' and the degrees of 'privacy' required, can have a 'housing use' today.

The 'housing use' has quietly carried out a pedagogy that establishes behavioral patterns that can be reproduced anywhere; and a spatial disinhibition that makes it possible to reproduce them in different places, until they become dwellings even temporarily. It is for all this, that we can say that 'the house educates'. 


\section{ACKNOWLEDGEMENTS}

MINISTERIO DE ECONOMÍA Y COMPETITIVIDAD

Programa Estatal de Investigación, Desarrollo e Innovación Orientada a los Retos de la Sociedad 2014-2017

\section{REFERENCES}

[1] X. Monteys, M. Mària, P. Fuertes, R. Sauquet and N. Salvadó. Atlas del aprovechamiento arquitectónico. Estudio crítico de los edificios reutilizados en Barcelona, MINECO 20162018.

[2] Plan General Metropolitano de Barcelona, 1976.

[3] Los cinco puntos para una nueva arquitectura de Le Corbusier eran: los pilotis, la terraza ajardinada, la planta libre, la ventana alargada y la fachada libre. Ver: Le Corbusier et Pierre Jeanneret (1926): Les Cinq Points d'une Architecture Nouvelle

[4] Le Corbusier et Pierre Jeanneret (1926): op. cit. 